\title{
Physical and genetic map of the Clostridium saccharobutylicum (formerly Clostridium acetobutylicum) NCP 262 chromosome
}

\author{
Stefanie Keis, John T. Sullivan and David T. Jones
}

Department of Microbiology, University of Otago, Dunedin, New Zealand

Author for correspondence: David T. Jones. Tel: +6434797735. Fax: +6434798540. e-mail: david.jones@stonebow.otago.ac.nz

\begin{abstract}
A physical and genetic map of the Clostridium saccharobutylicum NCP 262 chromosome was constructed. The order of macrorestriction fragments was determined by analysing fragments generated after single and double digestion with the restriction enzymes BssHII, I-Ceul, Sse8387I, Rsrll and Sfil and separation by PFGE. The I-Ceul backbone of C. saccharobutylicum was constructed by indirect end-labelling with rrs- and 3' rrl-specific probes located on either side of the I-Ceul site in the rrn operon, and reciprocal separation of BssHII and I-Ceul digestion products by two-dimensional PFGE. The positions of BssHII fragments on the physical map were determined using a library of linking clones containing BssHII cleavage sites. The size of the circular genome was estimated to be $5.3 \mathrm{Mb}$ with a mean resolution of approximately $140 \mathrm{~kb}$. The chromosome of $C$. saccharobutylicum contains 12 rrn operons, located on $46 \%$ of the chromosome, which are transcribed divergently from the deduced origin of replication. The genetic map was constructed by determining the location of 28 genes involved in house-keeping, heat-shock response, sporulation, electron transfer and acid- and solvent-formation. Comparison of the $C$. saccharobutylicum genetic map with those of the spore-forming bacteria Bacillus subtilis, Clostridium acetobutylicum, Clostridium perfringens and Clostridium beijerinckii indicated C. saccharobutylicum to be most similar to the latter two Clostridium species, with the order of the genes within the gyrAB and recA loci being conserved.
\end{abstract}

Keywords: solvent-producing clostridia, PFGE, 2D-PFGE, linking library, genome organization

\section{INTRODUCTION}

Clostridium saccharobutylicum (formerly Clostridium acetobutylicum) NCP 262 is an obligately anaerobic spore-forming bacterium and one of four distinct species of solvent-producing clostridia capable of fermenting various carbohydrates to produce acetone and butanol (Johnson et al., 1997; Keis et al., 1995). Solventproducing clostridia were used extensively during the early part of the twentieth century for the commercial production of solvents (Jones \& Woods, 1986). Both the industrial acetone-butanol fermentation process and the solvent-producing clostridia have continued as an active

Abbreviation: 2D, two-dimensional. focus of research due to their potential applications in biotechnology.

The first successful industrial solvent-producing strains to be isolated, patented and used for the large-scale production of solvents from starch-based substrates were classified as C. acetobutylicum. Following the switch to molasses as the preferred fermentation substrate for commercial fermentation during the mid1930s, numerous new saccharolytic, solvent-producing clostridial strains were isolated that performed more efficiently on these sugar-based substrates. Many of these new industrial strains were patented under novel species names but none of these were recognized as legitimate species. Once the acetone-butanol fermentation process declined during the latter part of the twentieth century these names fell into disuse. Sub- 
sequently, the majority of the industrial solvent-producing clostridial strains became designated as either $C$. acetobutylicum or Clostridium beijerinckii. Recent studies have, however, revealed that the various strains of industrial solvent-producing clostridia belong to four distinct species: C. acetobutylicum, C. beijerinckii, C. saccharobutylicum and 'Clostridium saccharoperbutylacetonicum' (Johnson et al., 1997; Keis et al., 1995), with the latter two species in the process of being formally classified (S. Keis, R. Shaheen \& D. T. Jones, unpublished results).

Most of the studies undertaken over the last two decades have focused on strains belonging to the species $C$. acetobutylicum and C. beijerinckii, which are phylogenetically only distantly related (Johnson et al., 1997; Keis et al., 1995). Physical and genetic maps of the chromosomes of these two species have been published (Cornillot et al., 1997; Wilkinson \& Young, 1995), and the entire C. acetobutylicum genome sequence has now been determined (http://www.genomecorp.com/ sequence_centre/bacterial_genomes/).

Industrial strains belonging to the recently named $C$. saccharobutylicum species were amongst the most successful saccharolytic, solvent-producing clostridia utilized for the commercial production of solvents from molasses (Jones \& Keis, 1995; Keis et al., 1995; Shaheen et al., 2000). Nevertheless, C. saccharobutylicum has been less intensively studied than the other two solvent-producing species and currently little is known about the genomic structure and organization of this organism.

In this study, we have used one- and two-dimensional (2D) PFGE, BssHII linking clones, and Southern hybridization analysis to construct a physical and genetic map of the C. saccharobutylicum type strain, NCP 262. The size of the circular chromosome was estimated to be $5 \cdot 3 \mathrm{Mb}$ and it contains $12 \mathrm{rrn}$ operons that are transcribed divergently from the origin of replication. The genetic map of this species was compared with those of the spore-forming bacteria Bacillus subtilis, C. acetobutylicum, C. beijerinckii and Clostridium perfringens.

\section{METHODS}

Bacterial strains, plasmids and culture conditions. The bacterial strains and plasmids used in this study are listed in Table 1. C. saccharobutylicum NCP 262 was grown anaerobically in Clostridium Basal Medium (CBM) (O'Brien \& Morris, 1971). Escherichia coli was grown aerobically at $37^{\circ} \mathrm{C}$ in $2 \times$ YT broth or Luria-Bertani (LB) agar (Sambrook et al., 1989) supplemented as required with $100 \mu \mathrm{g}$ ampicillin $\mathrm{ml}^{-1}, 50 \mu \mathrm{g}$ kanamycin $\mathrm{ml}^{-1}, 24 \mu \mathrm{g} \mathrm{IPTG} \mathrm{ml}^{-1}$ and

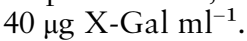

Chromosomal DNA preparation and restriction enzyme digestions. Chromosomal DNA embedded in agarose plugs was prepared as described previously (Keis et al., 1995). Restriction enzymes were purchased from New England Biolabs and Roche Molecular Biochemicals, except for Sse8387I, which was obtained from Amersham. Slices of DNA plugs $(200 \mu \mathrm{l})$ were equilibrated three times at room tem- perature for $15 \mathrm{~min}$ in $100 \mu \mathrm{l}$ of the restriction enzyme buffer recommended by the manufacturer, with the exception of $B s s$ HII digests, which were equilibrated and digested in $1 \times$ KGB buffer $(100 \mathrm{mM}$ potassium glutamate, $25 \mathrm{mM}$ Tris/acetate $\mathrm{pH} 7 \cdot 6,10 \mathrm{mM}$ magnesium acetate, $50 \mu \mathrm{g}$ bovine serum albumin $\mathrm{ml}^{-1}, 0.5 \mathrm{mM}$ 2-mercaptoethanol) (McClelland et al., 1988). Plugs were then digested with $10 \mathrm{U}$ restriction enzyme at the optimum temperature for $3 \mathrm{~h}$. Double digestions of DNA plugs were carried out consecutively. For reproducibility, agarose plugs digested with I-CeuI were treated after digestion with $0.5 \mathrm{mg}$ proteinase $\mathrm{K} \mathrm{ml}^{-1}$ in ES buffer $(0.5 \mathrm{M}$ EDTA pH 9.0, $1 \%$, w/v, N-lauroyl-sarcosine) for $30 \mathrm{~min}$ at $56^{\circ} \mathrm{C}$ and washed twice with TE buffer (10 mM Tris/HCl, $1 \mathrm{mM}$ EDTA, pH 8.0) for $10 \mathrm{~min}$ at room temperature.

For 2D digestions, a 4-mm-wide slice of the lane, containing the first digestion, was equilibrated in a $15 \mathrm{ml}$ polypropylene tube for $30 \mathrm{~min}$ at $4{ }^{\circ} \mathrm{C}$ with $2 \mathrm{ml}$ of the second restriction enzyme buffer. The DNA slice was then preincubated overnight at $4{ }^{\circ} \mathrm{C}$ in $2 \mathrm{ml}$ restriction enzyme buffer containing $100 \mathrm{U}$ enzyme to allow the enzyme to diffuse into the agarose slice. This was followed by incubation in a Hybaid oven at the appropriate temperature with slow rotation for $3 \mathrm{~h}$.

Pulsed-field and agarose gel electrophoresis. PFGE was performed in a contour-clamped homogeneous electric field (CHEF) electrophoresis system (CHEF-DRIII, Bio-Rad). Agarose plugs were equilibrated three times in $0.5 \times \mathrm{TBE}$ buffer ( $45 \mathrm{mM}$ Tris/borate, $1 \mathrm{mM}$ EDTA) for $15 \mathrm{~min}$ prior to loading agarose (Molecular Biology Grade; Bio-Rad) gels. Gels were routinely subjected to electrophoresis at $6 \mathrm{~V} \mathrm{~cm}^{-1}$, $14{ }^{\circ} \mathrm{C}$, at an included angle of $120^{\circ}$. Agarose concentrations, pulse times and total running times varied according to the size range of fragments to be separated; gel electrophoresis conditions for individual experiments are described in the figure legends. Lambda DNA concatemers with lambda HindIII-digested fragments (Low Range PFG Marker; New England Biolabs), lambda concatemers (Lambda Ladder PFG Marker; New England Biolabs), and chromosomes of Saccharomyces cerevisiae YNN295 (Bio-Rad) were used as molecular size standards. Conventional agarose gels were subjected to electrophoresis at $1.4 \mathrm{~V} \mathrm{~cm}^{-1}$ for $18 \mathrm{~h}$ and lambda DNA digested with HindIII was used as a size standard.

Southern hybridization. DNA fragments separated by PFGE were transferred onto Hybond- $\mathrm{N}^{+}$nylon membranes (Amersham) using a VacuGene (Pharmacia-LKB) vacuum blotting system. The DNA was depurinated with $0 \cdot 25 \mathrm{M} \mathrm{HCl}$ for $20 \mathrm{~min}$, denatured (in $1.5 \mathrm{M} \mathrm{NaCl}, 0.5 \mathrm{M} \mathrm{NaOH}$ ) for $1 \mathrm{~h}$, and transferred in $20 \times$ SSC $(1 \times$ SSC is $0.15 \mathrm{M} \mathrm{NaCl}$ plus $0.015 \mathrm{M}$ sodium citrate) for $2 \mathrm{~h}$. DNA in conventional agarose gels was depurinated, denatured and transferred for $10 \mathrm{~min}$, $10 \mathrm{~min}$ and $1 \mathrm{~h}$, respectively.

Plasmid DNA used for probing was isolated with the High Pure plasmid isolation kit (Roche Molecular Biochemicals). PCR products used as probes were extracted from $1 \%(\mathrm{w} / \mathrm{v})$ SeaPlaque low-melting-point agarose (FMC BioProducts) gels using the QIAEXII gel extraction kit (Qiagen).

DNA was labelled with $\left[\alpha^{32} \mathrm{P}\right] \mathrm{dCTP}$ (Amersham) by random priming using the RTS RadPrime DNA labelling kit (GibcoBRL). Prehybridization and hybridization were carried out in the same hybridization buffer (Church \& Gilbert, 1984) at $65^{\circ} \mathrm{C}$ for 18 to $24 \mathrm{~h}$. After hybridization, membranes were washed sequentially for $5 \mathrm{~min}$ in $2 \times \mathrm{SSC} / 0 \cdot 1 \%$ SDS $\left(37^{\circ} \mathrm{C}\right)$, $20 \mathrm{~min}$ in $1 \times \mathrm{SSC} / 0 \cdot 1 \% \operatorname{SDS}\left(65^{\circ} \mathrm{C}\right)$, and $20 \mathrm{~min}$ in $0 \cdot 1 \times$ SSC $/ 0 \cdot 1 \%$ SDS $\left(65^{\circ} \mathrm{C}\right.$ ) before exposure to X-ray film (Cronex, DuPont). For heterologous probes, membranes were washed 
Table 1. Bacterial strains, plasmids and PCR product used in this study

\begin{tabular}{|c|c|c|c|}
\hline Strain or plasmid & Relevant characteristics & Source & Reference \\
\hline \multicolumn{4}{|l|}{ C. saccharobutylicum } \\
\hline NCP 262 & Wild-type & & \\
\hline \multicolumn{4}{|l|}{ E. coli } \\
\hline DH10B & $\begin{array}{l}\mathrm{F}^{-} m c r A \Delta(m r r-h s d R M S-m c r B C) \phi 80 \mathrm{~d} l a c Z \Delta M 15 \\
\Delta l a c X 74 \text { deoR recA1 endA1 araD139 } \Delta(\text { ara, } \\
\text { leu } 7697 \text { galU galK } \lambda^{-} \text {rpsL nup } G\end{array}$ & & Hanahan et al. (1991) \\
\hline \multicolumn{4}{|l|}{ Plasmids } \\
\hline pUC8 & Cloning and sequencing vector & & Yanisch-Perron et al. (1985) \\
\hline pNEB193 & pUC19-derived vector & & New England Biolabs \\
\hline pUC4K & Contains kanamycin cassette & & Vieira \& Messing (1982) \\
\hline pJP3 & $g \ln A$ (glutamine synthetase) & C. saccharobutylicum & Janssen et al. (1988) \\
\hline pAT-1 & spoIID (sporulation) & C. saccharobutylicum & S. Reid* \\
\hline pCar1 & $\operatorname{reg} A$ (ccpA homologue) & C. saccharobutylicum & Davison et al. (1995) \\
\hline pHS92 & metF (methionine synthase) & C. saccharobutylicum & Stutz $(2000)$ \\
\hline pWT1 & sum (metronidazole susceptibility) & C. saccharobutylicum & Collett et al. (1997) \\
\hline pCADH-463 & adb1 (alcohol dehydrogenase) & C. saccharobutylicum & Youngleson et al. (1989) \\
\hline $\mathrm{pF} 2$ & aad (alcohol/aldehyde dehydrogenase) & C. saccharobutylicum & This study \\
\hline pHZ301 & $x y l A$ (xylanase) & C. saccharobutylicum & Zappe et al. (1987) \\
\hline pHZ100 & eglA (endoglucanase) & C. saccharobutylicum & Zappe et al. (1986) \\
\hline pCBS2 & $\operatorname{scr} B$ (sucrase operon) & C. beijerinckii & Reid et al. (1999) \\
\hline pEK30 & ISCb1 (partial IS element) & C. beijerinckii & Liyanage et al. (2000) \\
\hline pSU1 & $\begin{array}{l}r e c F ; \text { gyrA gyrB (homologous recombination, } \\
\text { DNA gyrases) }\end{array}$ & C. acetobutylicum & Ullmann \& Dürre (1996) \\
\hline prec1 & $r e c A$ (recombination) & C. acetobutylicum & Cornillot et al. (1997) \\
\hline pKG3 & dnaKJ (hsp70 cluster) & C. acetobutylicum & Narberhaus et al. (1992) \\
\hline pMFH1 & bydA (complete locus) & C. acetobutylicum & Gorwa et al. (1996) \\
\hline pJC7 & butK, $p t b$ (butyrate operon) & C. acetobutylicum & Walter et al. (1993) \\
\hline $\mathrm{pK} 42$ & hsp18 trna $_{\mathrm{ACG}}$ & C. acetobutylicum & Sauer \& Dürre (1993) \\
\hline $\mathrm{pFN} 4$ & groESL (hsp10-60 operon) & C. acetobutylicum & Narberhaus \& Bahl (1992) \\
\hline pb37 & hbd (BCS operon) & C. acetobutylicum & Boynton et al. (1996) \\
\hline pCoAT4 & ctfAB (sol operon) & C. acetobutylicum & Cary et al. (1990) \\
\hline pEco14 & $b d h A B$ (butanol dehydrogenases) & C. acetobutylicum & Walter et al. (1992) \\
\hline pEC10 & $r r l\left(3^{\prime}\right.$ end of $23 S$ rRNA gene) & C. perfringens & Cornillot et al. (1997) \\
\hline PCR probe $16 \mathrm{SrRNA}$ & rrs (position 830-1383, E. coli numbering) & C. saccharobutylicum & Keis et al. (1995) \\
\hline
\end{tabular}

*Personal communication.

less stringently by carrying out the initial wash as above, followed by $20 \mathrm{~min}$ in $2 \times \mathrm{SSC} / 0 \cdot 1 \% \mathrm{SDS}$ at $50{ }^{\circ} \mathrm{C}$.

Genomic library construction and cloning of small BssHII fragments. Genomic DNA was extracted from agarose plugs using the QIAEXII gel extraction kit (Qiagen). The DNA was sheared by nebulization and end-repaired with T4 DNA polymerase (Roche Molecular Biochemicals) and Klenow (Roche Molecular Biochemicals) (Andersson et al., 1996). The end-repaired DNA was separated on a $1 \%(\mathrm{w} / \mathrm{v})$ SeaPlaque low-melting-point agarose (FMC BioProducts) gel. DNA ranging from 4 to $23 \mathrm{~kb}$ was excised from the gel, and the DNA was extracted using the QIAEXII gel extraction kit, followed by ligation into dephosphorylated, SmaI-digested pUC8. For the cloning of small $(<5 \mathrm{~kb})$ BssHII fragments, DNA was extracted from BssHII-digested genomic DNA plugs and ligated into dephosphorylated BssHII-digested pNEB193. Electrocompetent E. coli cells were transformed by electroporation and white ampicillin-resistant transformants were selected on media containing X-Gal, IPTG and ampicillin.
Preparation of linking clones. The kanamycin cassette from pUC4K was amplified using the PCR conditions described below and the primers KANFWD (5'-TCGACTACGCGTAGCTTCACGCTGCCGCAAGC- $\left.3^{\prime}\right)$ and KANREV (5'AGTACGACGCGTGGGGTGGGCGAAGAACTCCA-3'), each containing $M l u \mathrm{I}$ recognition sites (shown in bold) near their $5^{\prime}$ ends. This cassette was digested with $M l u$ I to create a kanamycin cassette with BssHII-compatible ends.

Plasmid DNA was isolated from the library of pooled recombinant NCP 262 random pUC8 clones using a Qiagen maxi-prep kit. The DNA was digested with BssHII, treated with alkaline phosphatase (Roche Molecular Biochemicals) and ligated with the MluI-digested kanamycin cassette. Clones with C. saccharobutylicum NCP 262 DNA containing the rare $B s s \mathrm{HII}$ restriction enzyme site were obtained by selection on media containing ampicillin and kanamycin. These linking clones were radiolabelled and hybridized to Southern blots of PFGE-separated restriction digests as described above.

Sequence analysis of linking clones. Plasmid DNA from linking clones was prepared for sequencing using a Quantum 
Prep plasmid miniprep kit (Bio-Rad). BssHII linking clones were sequenced with the following specifically designed primers, SEQKANLEFT (5'-CCAGTAGCTGACATTCATCCG-3') and SEQKANRIGHT (5'-AGGTTGGGCTTCGGAATCGT-3'), which were complementary to the DNA sequences at either end of the kanamycin cassette. Sequencing was carried out using a BigDye terminator cycle sequencing ready reaction sequencing kit (Applied Biosystems) and a model ABI377 automated DNA sequencer (Applied Biosystems).

Homology searches of non-redundant databases at the National Centre for Biotechnology Information, using BLASTX and BLASTN (Altschul et al., 1997), were done through the WWW BLAST Server (www.ncbi.nlm.nih.gov).

Confirmation of BssHIl-linked fragments by PCR. Synthetic primers, based on sequences obtained from linking clones, were designed to amplify products of approximately $400 \mathrm{bp}$ which spanned NCP 262 genomic BssHII sites. PCR was carried out using the Expand High Fidelity PCR system (Roche Molecular Biochemicals) and NCP 262 genomic DNA embedded in agarose plugs was used as the template. The PCR programme consisted of an initial cycle of denaturation $\left(94^{\circ} \mathrm{C}\right.$ for $2 \mathrm{~min})$, annealing $\left(50^{\circ} \mathrm{C}\right.$ for $\left.2 \mathrm{~min}\right)$ and extension $\left(72{ }^{\circ} \mathrm{C}\right.$ for $5 \mathrm{~min}$ ). This was followed by 30 cycles of $94^{\circ} \mathrm{C}$ for $30 \mathrm{~s}$, $50{ }^{\circ} \mathrm{C}$ for $30 \mathrm{~s}$ and $72{ }^{\circ} \mathrm{C}$ for $1 \mathrm{~min}$, and a final cycle of $94{ }^{\circ} \mathrm{C}$ for $1 \mathrm{~min}, 50^{\circ} \mathrm{C}$ for $1 \mathrm{~min}$, and $72^{\circ} \mathrm{C}$ for $5 \mathrm{~min}$. PCR products were purified, radiolabelled and hybridized to PFGE-separated restriction digests as described above. Purified PCR products were also sequenced as described above with their respective PCR primers.

\section{RESULTS}

\section{Restriction fragment analysis and estimation of genome size}

The $\mathrm{G}+\mathrm{C}$ content of the genomes of mesophilic Clostridium species is less than $30 \mathrm{~mol} \%$; therefore restriction enzymes with $\mathrm{GC}$-rich recognition sites were screened to select those with a limited number of cleavage sites on the genome of NCP 262. NaeI, NarI, SmaI, EagI, KspI and BglI all produced too many fragments $(>20)$ to be suitable for mapping. By contrast, NotI did not cleave the NCP 262 genome. Enzymes chosen for mapping were BssHII and Sse8387I and the intron-encoded endonuclease I-CeuI, which cleaves within the $r r l$ (23S) genes of $r r n$ operons. These enzymes produced 16, 8 and 12 fragments, respectively (Table 2, Fig. 1).

A low-resolution physical map of C. beijerinckii NCIMB 8052 was constructed by Wilkinson \& Young (1995) using the enzymes RsrII and SfII. We found the genome of NCP 262 to be cleaved twice by RsrII and once by $S f i \mathrm{I}$, as determined after double digestion with BssHII and ICeuI. Hence, we included the RsrII and SfiI sites on the physical map.

The enzyme ApaI was also found to yield a suitable number of fragments (12-20), several of which comigrated with those of I-CeuI. This is due to the presence of an ApaI site in the rrs gene of the $r r n$ operon, as confirmed by analysis of the $16 \mathrm{~S}$ rRNA gene sequence of NCP 262 (GenBank accession number U16147; Keis
Table 2. Sizes of restriction fragments generated by cleavage of the C. saccharobutylicum NCP 262 chromosome

\begin{tabular}{|lccccc|}
\hline \multirow{2}{*}{ Fragment } & \multicolumn{5}{c|}{ Fragment size (kb)* obtained with: } \\
\cline { 2 - 6 } & BssHII & I-CeuI & Sse8387I & RsrII & SfiI \\
\hline A & $1151 \pm 29$ & $2908 \dagger$ & $1794 \dagger$ & $4774 \dagger$ & $5337 \neq$ \\
B & $631 \pm 8$ & $1039 \pm 14$ & $1555+$ & $563 \pm 8$ & \\
C & $598 \pm 9$ & $675 \pm 6$ & $855 \pm 6$ & & \\
D & $417 \pm 5$ & $316 \pm 7$ & $497 \pm 11$ & & \\
E & $395 \pm 5$ & $159 \pm 3$ & $362 \pm 6$ & & \\
F & $372 \pm 5$ & $112 \pm 1$ & $194 \pm 3$ & & \\
G & $320 \pm 5$ & $74 \pm 2$ & $35 \pm 2 \$$ & & \\
H & $306 \pm 7$ & $17 \pm 1$ & & & \\
I & $238 \pm 3$ & $9 \cdot 6$ & & & \\
J & $219 \pm 5$ & $8 \cdot 5$ & & & \\
K & $205 \pm 5$ & $6 \cdot 5$ & & & \\
L & $192 \pm 6$ & $6 \cdot 1$ & & & \\
M & $145 \pm 2$ & & & & \\
N & $69 \pm 3 \mathbb{S}$ & & & & \\
O & 5 & & & & \\
Total & 5332 & 5331 & 5327 & & \\
\hline
\end{tabular}

*The size indicated is the mean \pm standard deviation for at least five independent values, except where otherwise noted.

† The sizes of bands CeuA, SseA and SseB were obtained by summing the sizes of fragments related to them from double digestions with BssHII $(\mathrm{CeuA}=1151+417+395+339+238+$ $192+145+26+5=2908 ;$ SseA $=565+347+320+219+205+$ $69+69=1794 ; \quad$ SseB $=417+395+306+236+145+51+5=$ 1555). The size of RsrA was obtained by subtracting RsrB from the mean total genome size of $5337 \mathrm{~kb}$.

$\ddagger$ Single recognition site.

\$Fragment is a doublet.

et al., 1995). Since ApaI sites would lie in close proximity to I-CeuI sites in most instances, ApaI was not used for mapping.

The size of the C. saccharobutylicum genome was estimated to be $5 \cdot 3 \mathrm{Mb}$ by summation of the fragments obtained from individual BssHII, I-CeuI, Sse8387I and RsrII digestions (Table 2) and from BssHII/I-CeuI, ICeuI/Sse8387I and BssHII/Sse8387I double digestions (Table 3, Fig. 1). The fragment sizes were determined from at least five different gels using different PFGE parameters. Attempts to resolve the CeuA and RsrA fragments using PFGE conditions recommended by BioRad for the separation of Hansenula wingei and Schizosaccharomyces pombe chromosomes were not successful. Hence, the sizes of CeuA and RsrA were obtained by analysis of double digests. Fragments SseA and SseB could not be separated (Fig. 1c), and as a consequence their sizes were also determined more accurately from double digestions. The smallest Bss HII fragment (BssO) was not observed in pulsed-field gels nor in conventional agarose gels but was detected by hybridization (see Fig. 3). 
(a)

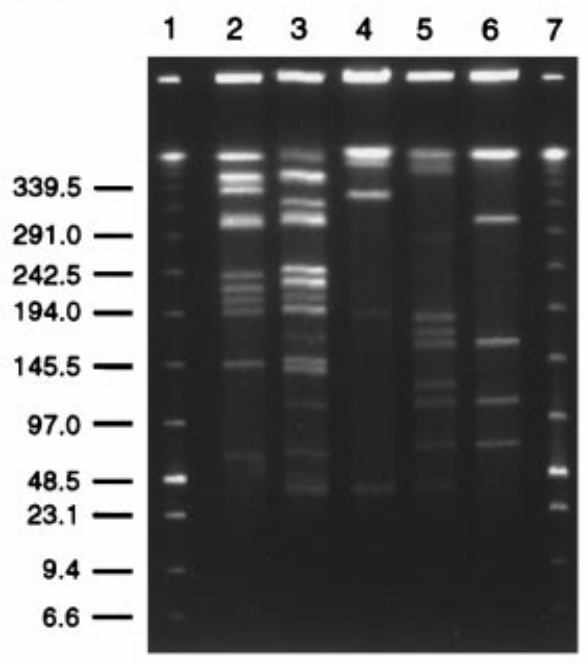

(b)

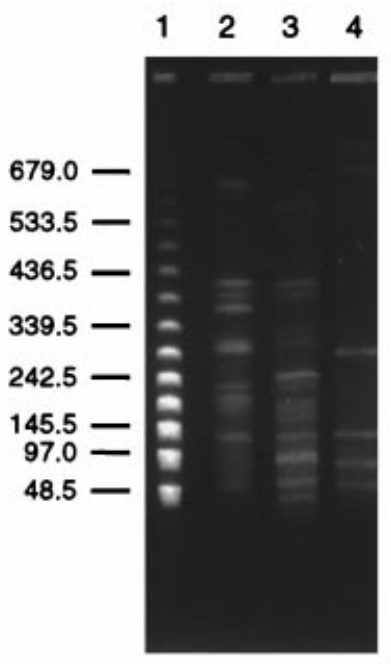

(c)

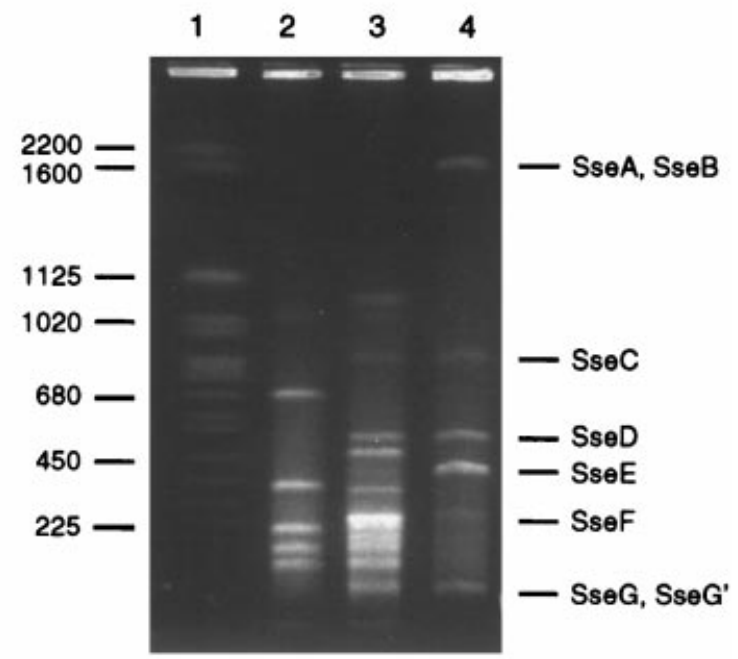

Fig. 1. PFGE of restriction enzyme digests of C. saccharobutylicum NCP 262 DNA. (a) DNA was digested with BssHII (lane 2), BssHII/Sse8387I (lane 3), Sse8387I (lane 4), Sse8387I/I-Ceul (lane 5) and I-Ceul (lane 6). The Low Range PFG Marker (New England Biolabs) was used as a molecular size marker (lanes 1 and 7). Electrophoresis was performed in $1.2 \%$ agarose and the pulse time was ramped from 5 to $30 \mathrm{~s}$ for $24 \mathrm{~h}$. (b) DNA was digested with BssHII (lane 2), BssHII/I-Ceul (lane 3) and I-Ceul (lane 4). The Lambda Ladder PFG Marker (New England Biolabs) was used as a molecular size marker (lane 1). Electrophoresis was performed in $1.1 \%$ agarose and the pulse time was ramped from 20 to $50 \mathrm{~s}$ for $20 \mathrm{~h}$. (c) DNA was digested with I-Ceul (lane 2), Sse8387I/I-Ceul (lane 3) and Sse8387I (lane 4). The Sse8387I fragments are indicated. Electrophoresis was performed in $1 \%$ agarose and the pulse time was ramped from 60 to $120 \mathrm{~s}$ for $22 \mathrm{~h}$. The yeast chromosomes of S. cerevisiae YNN 295 (Bio-Rad) were used as a molecular marker (lane 1). All sizes are in kilobases.

\section{Construction of the I-Ceul physical map}

The intron-encoded endonuclease I-CeuI has been found to cleave exclusively within $r r l$ genes, allowing the enumeration of $r r n$ operons of a given bacterium. Digestion of the NCP 262 genome with I-CeuI generated 12 fragments, ranging in size from $5 \mathrm{~kb}$ to $2900 \mathrm{~kb}$ (Table 2), indicating that this species contains $12 \mathrm{rrn}$ operons. The circular genomic backbone of NCP 262, as defined by the position of the rrn operons and their orientation with respect to the origin of replication, was constructed using a strategy similar to that devised by Cornillot et al. (1997). This involved probing Southern blots of single and double BssHII and I-CeuI digestions with a labelled PCR product specific to the rrs (16S) gene located on one side of the I-CeuI site, and a probe (pEC10) containing the 3' end of the $r r l$ gene located on the other side of the I-CeuI site. All resolvable I-CeuI fragments hybridized with both the rrs and 3' rrl probes, except for CeuG, which hybridized only with the rrs probe at twice the intensity of the other fragments (data not shown), indicating that the rrn operons are transcribed divergently from within this fragment. All the $B s s$ HII fragments that were cleaved by I-CeuI, and no other BssHII fragments, hybridized with both the rrs and $3^{\prime} r r l$ probes, with the BssH fragment hybridizing at high intensity (data not shown).

This indirect end-labelling approach was then combined with 2D-PFGE. The NCP 262 genome was digested with I-CeuI and separated by PFGE in the first dimension, followed by digestion with BssHII and separation in the second dimension (or vice versa) (Fig. 2a). This allowed the arrangement of the $\mathrm{I}-\mathrm{CeuI}$ restriction sites to be determined by identifying the BssHII fragments that overlapped each I-CeuI site. CeuA, CeuB, CeuC, CeuD and CeuE were the only I-CeuI fragments cleaved by BssHII (Table 4). Inversely, BssB, BssC, BssF, BssH and Bss J were the only fragments cut by I-CeuI (Fig. 2). BssB was cut by I-CeuI yielding two fragments of $577 \mathrm{~kb}$ (BC1) and $53 \mathrm{~kb}$ (BC7), which hybridized with the $3^{\prime}$ rrl and rrs probe, respectively (Fig. 2b). The $577 \mathrm{~kb}$ fragment was also found on a 2D pulsed-field gel when CeuC was cleaved by BssHII in the second digestion, whereas the $53 \mathrm{~kb}$ fragment was obtained after BssHII digestion of CeuD (Table 4). Therefore, BssB spans the $\mathrm{I}-\mathrm{CeuI}$ site that joins CeuC and CeuD. CeuD produced a second fragment of $262 \mathrm{~kb}$ (BC3) after BssHII digestion (Table 4) and this fragment, which hybridized with the 3' rrl probe, was also released from BssF after I-CeuI digestion (Fig. 2b). BssF also yielded a rrs-specific $114 \mathrm{~kb}$ (BC6) fragment after I-CeuI digestion (Fig. 2b) and this fragment was also obtained after BssHII digestion of CeuE (Table 4); hence, BssF overlaps CeuD and CeuE. CeuE produced a 3' rrl-specific $53 \mathrm{~kb}$ (BC8) endfragment when digested with BssHII (Table 4) and this fragment was also found when $\mathrm{BssH}$ was digested by ICeuI and separated in the second dimension (Fig. 2b). Besides this $53 \mathrm{~kb}$ end-fragment, the BssH fragment not only contained the seven I-CeuI fragments CeuF to CeuL, it produced another end-fragment of $26 \mathrm{~kb}$ (BC10) after I-CeuI digestion which also hybridized only with the $3^{\prime} r r l$ probe (Fig. 2b). This indicated that the $r r n$ 
Table 3. Fragment sizes resulting from double digestions of the C. saccharobutylicum NCP 262 chromosome

\begin{tabular}{|c|c|c|c|c|c|c|c|c|c|}
\hline \multicolumn{10}{|c|}{ Name* and fragment size $(\mathbf{k b}) \dagger$ obtained with: } \\
\hline \multicolumn{2}{|c|}{ BssHII/I-CeuI } & \multicolumn{2}{|c|}{ I-CeuI/Sse8387I } & \multicolumn{2}{|c|}{ BssHII/Sse8387I } & \multicolumn{2}{|c|}{$R s r \mathrm{II} / \mathrm{I}-\mathrm{CeuI}$} & \multicolumn{2}{|c|}{ RsrII/Sse8387I } \\
\hline Fragment & Size & Fragment & Size & Fragment & Size & Fragment & Size & Fragment & Size \\
\hline BssA & $1151 \pm 29$ & CS1 & $1100 \pm 32$ & SseC & $855 \pm 6$ & $\mathrm{RC} 1$ & $1619 \ddagger$ & SseA & 1794 \\
\hline BC1 & $577 \pm 3$ & CeuB & $1039 \pm 14$ & SB1 & $565 \pm 7$ & CeuB & $1039 \pm 14$ & RS1 & $1252 \pm 37$ \\
\hline BssD & $417 \pm 5$ & SseC & $855 \pm 6$ & BssD & $417 \pm 5$ & $\mathrm{RC} 2$ & $726 \pm 12$ & SseC & $855 \pm 6$ \\
\hline BssE & $395 \pm 5$ & SseD & $497 \pm 11$ & BssE & $395 \pm 5$ & CeuC & $675 \pm 6$ & SseE & $362 \pm 6$ \\
\hline BC2 & $339 \pm 7$ & CS2 & $430 \pm 10$ & SB2 & $347 \pm 4$ & RsrB & $563 \pm 8$ & RS2 & $330 \pm 7$ \\
\hline BssG & $320 \pm 5$ & CS3 & $306 \pm 8$ & BssG & $320 \pm 5$ & CeuD & $316 \pm 7$ & RS3 & $260 \pm 5$ \\
\hline BC3 & $262 \pm 5$ & SseF & $194 \pm 3$ & BssH & $306 \pm 7$ & CeuE & $159 \pm 3$ & RS4 & $224 \pm 5$ \\
\hline BC4 & $260 \pm 4$ & CS4 & $186 \pm 4$ & SB3 & $236 \pm 5$ & CeuF & $112 \pm 1$ & SseF & $194 \pm 3$ \\
\hline BssI & $238 \pm 3$ & CS5 & $176 \pm 6$ & SB4 & $219 \pm 5$ & CeuG & $74 \pm 2$ & SseG & $35 \pm 2 \mathbb{S}$ \\
\hline BssK & $205 \pm 5$ & CeuE & $159 \pm 3$ & Bss J & $219 \pm 5$ & $\mathrm{CeuH}$ & $17 \pm 1$ & & \\
\hline BssL & $192 \pm 6$ & CS6 & $131 \pm 8$ & BssK & $205 \pm 5$ & CeuI & $9 \cdot 6$ & & \\
\hline BC5 & $175 \pm 3$ & CeuF & $112 \pm 1$ & BssL & $192 \pm 6$ & CeuJ & $8 \cdot 5$ & & \\
\hline BssM & $145 \pm 2$ & CeuG & $74 \pm 2$ & SB5 & $190 \pm 4$ & CeuK & $6 \cdot 5$ & & \\
\hline BC6 & $114 \pm 1$ & SseG & $35 \pm 2 \mathbb{S}$ & SB6 & $168 \pm 4$ & CeuL & $6 \cdot 1$ & & \\
\hline CeuF & $112 \pm 1$ & $\mathrm{CeuH}$ & $17 \pm 1$ & BssM & $145 \pm 2$ & & & & \\
\hline CeuG & $74 \pm 2$ & CeuI & $9 \cdot 6$ & SB7 & $138 \pm 2$ & & & & \\
\hline BssN & $69 \pm 3 \mathbb{S}$ & CeuJ & $8 \cdot 5$ & SB8 & $110 \pm 3$ & & & & \\
\hline BC7 & $53 \pm 3$ & CeuK & $6 \cdot 5$ & BssN & $69 \pm 3 \mathbb{S}$ & & & & \\
\hline BC8 & $53 \pm 3$ & CeuL & $6 \cdot 1$ & SB9 & $51 \pm 3$ & & & & \\
\hline BC9 & $37 \pm 2$ & & & SseG & $35 \pm 2 \mathbb{S}$ & & & & \\
\hline BC10 & $26 \pm 1$ & & & SB10 & $31 \pm 2$ & & & & \\
\hline $\mathrm{CeuH}$ & $17 \pm 1$ & & & $\mathrm{BssO}$ & 5 & & & & \\
\hline CeuI & $9 \cdot 6$ & & & & & & & & \\
\hline $\mathrm{CeuJ}$ & $8 \cdot 5$ & & & & & & & & \\
\hline CeuK & $6 \cdot 5$ & & & & & & & & \\
\hline CeuL & $6 \cdot 1$ & & & & & & & & \\
\hline BssO & 5 & & & & & & & & \\
\hline Total & 5336 & & 5337 & & 5322 & & 5331 & & 5341 \\
\hline
\end{tabular}

*Fragments resulting from double digestions are designated by a two-letter code followed by a number; the higher the number the smaller the fragment.

† The size indicated is the mean for at least five independent values, except where otherwise noted.

$\ddagger$ The size of RC1 was obtained by subtracting the sizes of fragments related to it $(\mathrm{RC} 1=2908-726-563=1619)$.

\Fragment is a doublet.

operons contained within this $\mathrm{BssH}$ fragment are confluently transcribed from CeuG, which hybridized only with the rrs probe and is contained within $\mathrm{BssH}$. The order of the I-CeuI fragments within BssH was not resolved.

CeuC (linked to CeuD as described above) also produced a $37 \mathrm{~kb}$ (BC9) rrs-specific end-fragment after BssHII digestion (Table 4), and this fragment was also obtained when Bss J was digested with I-CeuI (Fig. 2b). The other fragment that Bss J generated after I-CeuI digestion was a $175 \mathrm{~kb}$ (BC5) fragment, which hybridized with the rrs probe (Fig. 2b), and a fragment of this size was produced from CeuB after BssHII digestion (Table 4). Consequently, BssJ links CeuC to CeuB. The other endfragment that CeuB produced after Bss HII digestion in the second dimension was a $260 \mathrm{~kb}$ (BC4) rrs-specific fragment (Table 4) which was also obtained when BssC was digested with I-CeuI (Fig. 2b). Besides this fragment, BssC also generated a $339 \mathrm{~kb}$ (BC2) 3' rrl-specific endfragment (Table 4). At this stage the following I-CeuI fragments had been linked with their $3^{\prime} r r l$ endfragments as follows: BC2-CeuB-CeuC-CeuD-CeuE(CeuF to CeuL)-BC10, with the order of CeuF to CeuL unresolved. This left CeuA as the only fragment not accounted for and it was concluded that this large fragment closed the map into a circular genome via the $3^{\prime} r r l$-specific end-fragments BC2 and BC10.

\section{Alignment of the Sse8387I fragments}

The construction of the I-CeuI backbone of the genome of C. saccharobutylicum NCP 262 and the placement of a number of the BssHII fragments enabled the Sse8387I 
(a)

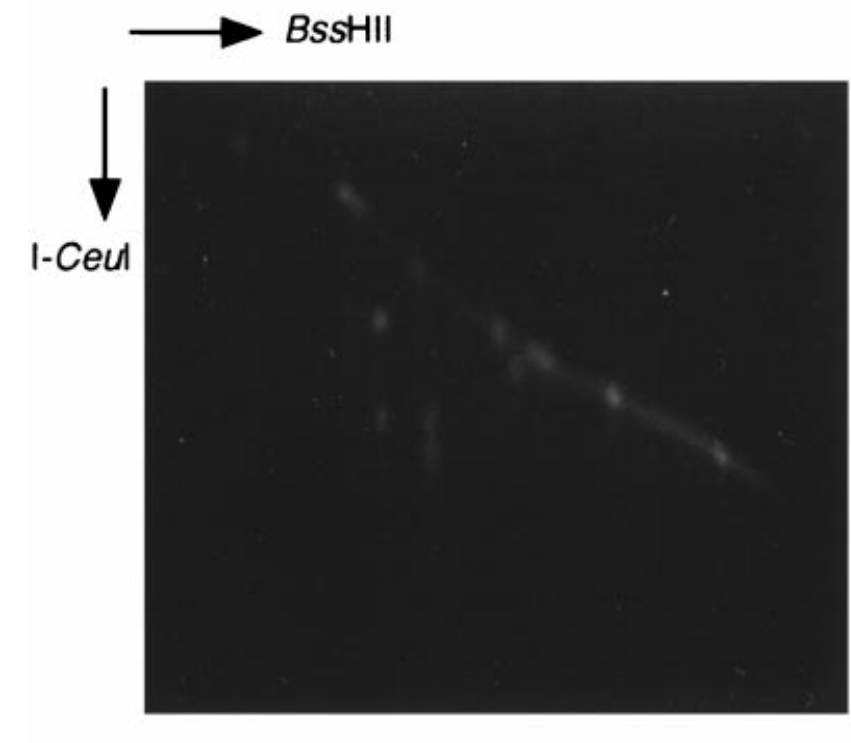

(b)

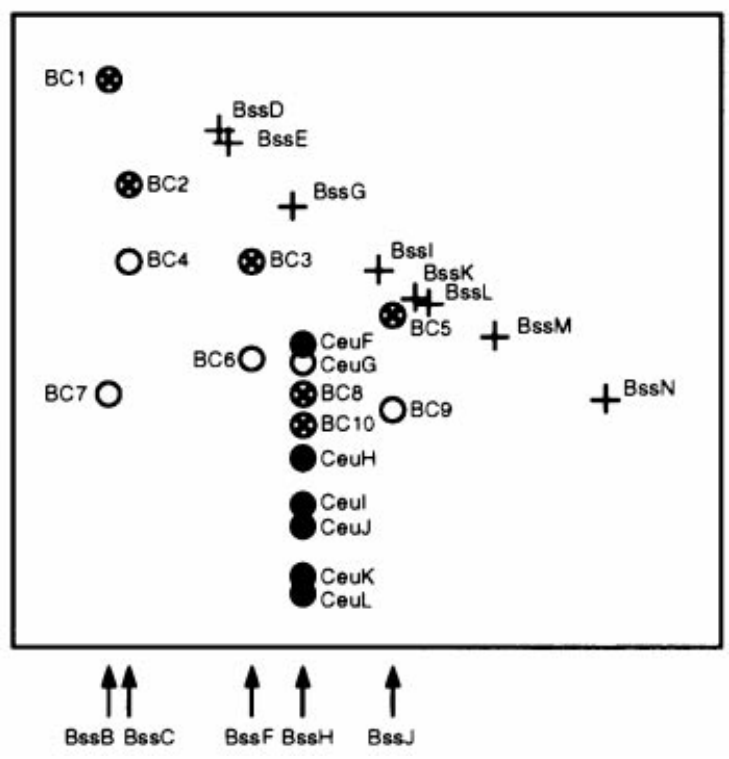

Fig. 2. Two-dimensional PFGE of complete BssHII/I-Ceul double digestions. (a) DNA was digested with BssHII and subjected to electrophoresis in the first dimension ( $1 \%$ agarose, ramped pulse time from 5 to $50 \mathrm{~s}$ for $24 \mathrm{~h}$ ), followed by digestion with I-Ceul in the second dimension (1.2\% agarose, pulse time of $25 \mathrm{~s}$ for $13 \mathrm{~h}$ and then $50 \mathrm{~s}$ for $6 \mathrm{~h}$ ). (b) Hybridization diagram summarizing the results with both ribosomal probes ( $3^{\prime} \mathrm{rrl}$ and $\mathrm{rrs}$ ). The small I-Ceul fragments (CeuH to CeuL) were not visible on the gel after ethidium bromide staining; however, these fragments gave strong signals when they hybridized with either ribosomal probe. Crossed circles indicate fragments that hybridized with the $3^{\prime}$ $r r l$ probe only. Open circles indicate fragments that hybridized with the rrs probe only, and black circles are I-Ceul fragments that hybridized with both ribosomal probes. The plus symbol depicts BssHII fragments not digested by I-Ceul. The Bss HII fragments cleaved by I-Ceul are shown below the arrows. See Table 3 for the sizes of the fragments. BssA was not resolved under these electrophoresis conditions.

Table 4. Sizes of fragments obtained after digestion of C. saccharobutylicum NCP 262 with I-Ceul in the first dimension and BssHII in the second dimension

\begin{tabular}{|ccccrc|}
\hline \multicolumn{5}{c|}{ Fragment size $(\mathbf{k b})$} \\
\cline { 2 - 6 } & CeuA & CeuB & CeuC & CeuD & CeuE \\
& & & & \\
& $339(\mathrm{BC} 2) *$ & $260(\mathrm{BC} 4) \dagger$ & $577(\mathrm{BC} 1)^{*}$ & $262(\mathrm{BC} 3)^{*}$ & $114(\mathrm{BC} 6) \dagger$ \\
& $26(\mathrm{BC} 10)^{* *}$ & $175(\mathrm{BC} 5)^{*}$ & $69(\mathrm{Bss})$ & $53(\mathrm{BC}) \dagger$ & $53(\mathrm{BC}))^{*}$ \\
Total & ()$\neq$ & ()$\neq$ & $37(\mathrm{BC} 9) \dagger$ & & 167 \\
\hline
\end{tabular}

*3' rrl-specific end-fragment.

†rrs-specific end-fragment.

$\ddagger$ The sizes of the remaining fragments are not given.

fragments to be located on the physical map. Double digestions of I-CeuI and Sse8387I generated six fragments (CS1 to CS6) (Table 3). SseA, SseB and SseE were cleaved by I-CeuI, and CeuA, CeuC and CeuD were cleaved by Sse8387I (Fig. 1a, c). Since CeuC and CeuD were linked and both were cleaved by Sse8387I, a Sse8387I fragment had to overlap this CeuC-CeuD linkage. The only Sse8387I fragment of the appropriate size that was cleaved by I-CeuI was SseE (362 kb), which produced the fragments CS4 $(186 \mathrm{~kb})$ and CS5 $(176 \mathrm{~kb})$. Subtracting the $186 \mathrm{~kb}$ fragment from CeuD $(316 \mathrm{~kb})$ left a $130 \mathrm{~kb}$ fragment and this accounted for the new CS6 fragment. Hence, it could be concluded that the CS5 fragment was situated within CeuC $(675 \mathrm{~kb})$. The remaining size difference of $499 \mathrm{~kb}$ for CeuC did not account for any of the new fragment sizes that resulted from a I-CeuI/Sse8387I double digestion. Partial Sse 8387I digestions produced fragments of about $395 \mathrm{~kb}$ 
Table 5. BssHII linking clones and their sequence homologies to genes or proteins from the genebank databases

\begin{tabular}{|c|c|c|c|c|c|}
\hline $\begin{array}{l}\text { Linking } \\
\text { clone }\end{array}$ & Linkage & Description of similar sequence* & $\begin{array}{l}\text { Source of similar } \\
\text { sequence }\end{array}$ & $\begin{array}{l}\text { Probability } \\
\text { score } \dagger\end{array}$ & $\begin{array}{c}\text { Accession } \\
\text { no. }\end{array}$ \\
\hline 25 & BssN-BssJ & $\begin{array}{l}\text { Transcriptional regulator AraC/XylS } \\
\text { family homologue YdeE }\end{array}$ & Bacillus subtilis & $2 e-56$ & G69777 \\
\hline 26 & BssO-BssI & $\mathrm{ND}$ & & & \\
\hline 27 & BssE-BssO & ND & & & \\
\hline A3 & BssM-BssE & $\begin{array}{l}\text { Hypothetical } 47 \cdot 0 \mathrm{kDa} \text { protein in } \\
g \ln Q \text {-ans } R \text { intergenic region }\end{array}$ & Bacillus subtilis & $2 e-53$ & P54545 \\
\hline A10 & BssF-BssH & Spore cortex-lytic enzyme (sleC) & Clostridium perfringens & $3 e-13$ & I 40824 \\
\hline B7 & $\begin{array}{l}\text { BssB-BssN } \\
\text { BssN'-BssG }\end{array}$ & Insertion element (ISCb1) & Clostridium beijerinckii & $1 e-165$ & AJ250468 \\
\hline B10 & BssD-BssM & ND & & & \\
\hline B12 & BssK-BssC & ND & & & \\
\hline $\mathrm{C} 2$ & BssH-BssD & Prolyl-tRNA & Micrococcus luteus & $5 e-13$ & X55109 \\
\hline $\mathrm{C} 4$ & BssL-BssA & ND & & & \\
\hline D4 & BssG-BssK & $\mathrm{ND}$ & & & \\
\hline F7 & BssC-BssA & $\begin{array}{l}\text { Hypothetical } \mathrm{ABC} \text { transporter permease } \\
\text { protein }\end{array}$ & Escherichia coli & $8 e-58$ & P77651 \\
\hline
\end{tabular}

*ND, No homology determined; linkage was confirmed by PCR.

† BLASTX (or BLASTN for linking clone C2) probability scores based on approximately 1200 bp of linked DNA sequence spanning BssHII sites.

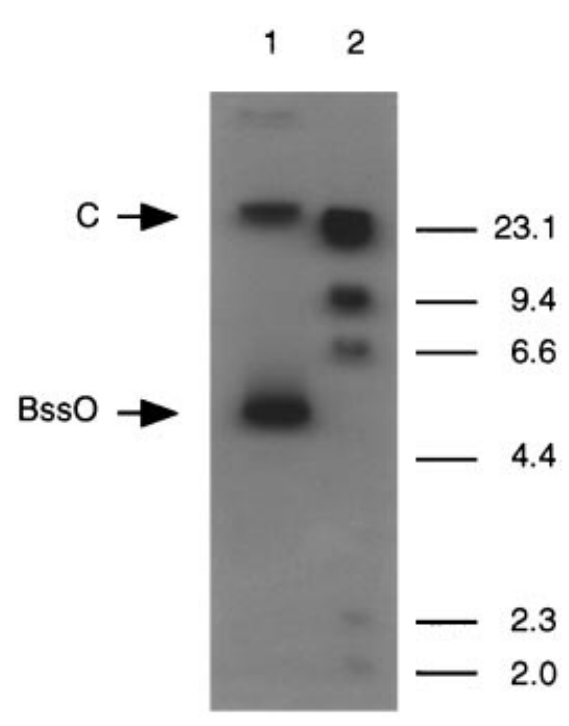

Fig. 3. Identification of the $5 \mathrm{~kb}$ BssO fragment as detected by Southern hybridization of digested NCP 262 genomic DNA probed with a PCR product spanning the BssHII site of linking clone 26. DNA was digested with Bss HII and separated in a conventional $1 \%$ agarose gel (lane 1). Lambda DNA digested with HindIII was used as a size marker (lane 2). The compression zone of fragments is indicated by ' $C$ '. All sizes are in kilobases.

and $430 \mathrm{~kb}$ (data not shown), and the only combination of linked Sse8387I fragments that would result in these sizes would be SseE-SseG and SseE-SseG-SseG', respectively. Therefore, SseG and SseG' $^{\prime}$ were located within CeuC, and the new $430 \mathrm{~kb}$ (CS2) fragment accounted for the remaining size difference. Since CeuC was linked to CeuB, and the latter was not cleaved by
Sse8387I, SseA had to bridge CeuB to produce a new fragment (CS3) of around $300 \mathrm{~kb}$. Similarly, the eight ICeuI fragments CeuE to CeuL did not contain Sse8387I sites, and the only Sse8387I fragment cleaved by I-CeuI large enough to produce the remaining new $1100 \mathrm{~kb}$ fragment (CS1) was SseB. SseF, SseC and SseD were not cleaved by I-CeuI and were therefore contained within CeuA. SseF (194 kb) was cleaved by BssHII producing fragments of about $168 \mathrm{~kb}$ (SB6) and $31 \mathrm{~kb}$ (SB10), which placed it adjacent to SseA. The orientation of SseC and SseD could not be resolved until the position of the RsrB fragment had been determined.

\section{Alignment of Rsrll fragments}

Double digestions of the NCP 262 genome with RsrII and I-CeuI produced two new fragments of $1619 \mathrm{~kb}$ (RC1) and $726 \mathrm{~kb}$ (RC2), with all of the resolvable I$\mathrm{CeuI}$ fragments remaining intact as well as the RsrB fragment (Table 3). Therefore, RsrB had to be located within CeuA. RsrB was placed more accurately on the physical map by analysis of a RsrII/Sse8387I double digestion. This digest generated four new fragments (Table 3), with SseB, SseD and RsrB being cleaved. RsrB $(563 \mathrm{~kb})$ was cleaved by Sse8387I to produce the fragments RS2 (330 kb) and RS4 (224 kb), with SseD overlapping the RsrB fragment by $224 \mathrm{~kb}$ and producing the third $260 \mathrm{~kb}$ fragment (RS3). The fourth $1252 \mathrm{~kb}$ fragment (RS1) was the result of SseB containing the second RsrII site.

\section{Positioning of the single Sfil site on the physical map}

The unique $S f i$ site was located on the physical map from the analysis of a BssHII/Sfi double digestion, 
(a)

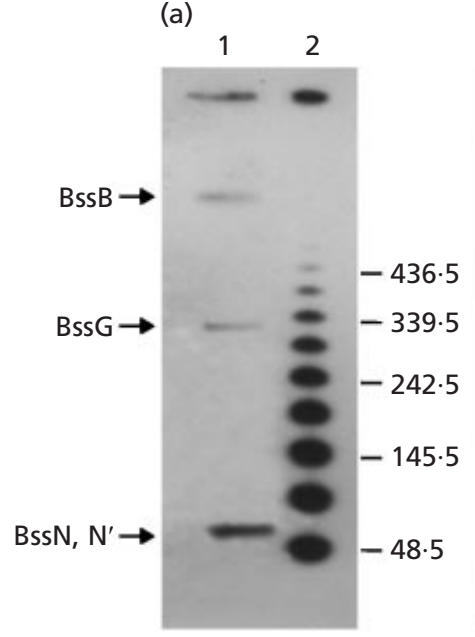

(b)

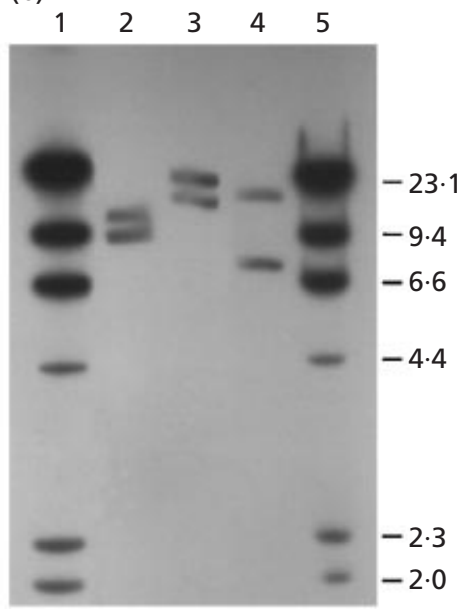

Fig. 4. Copy number of an IS element as detected by Southern hybridization of digested NCP 262 genomic DNA probed with a 378 bp PCR product. (a) DNA separated by PFGE in a $1.1 \%$ agarose gel with pulse times ramped from 5 to $50 \mathrm{~s}$ for $24 \mathrm{~h}$. Lane 1, BssHII fragments; lane 2, lambda DNA concatemers. (b) DNA separated in a conventional $1 \%$ agarose gel and digested with HindIII (lane 2), EcoRV (lane 3) and Xbal (lane 4). Lanes 1 and 5, lambda DNA digested with Hindlll. All sizes are in kilobases. which resulted in BssJ ( $219 \mathrm{~kb}$ ) being cleaved into two new fragments of about $195 \mathrm{~kb}$ and $25 \mathrm{~kb}$ (data not shown). The $S$ fiI site was placed more accurately by the analysis of a Sfil/I-CeuI double digestion, which generated two fragments of approximately $160 \mathrm{~kb}$ and $880 \mathrm{~kb}$, resulting from the cleavage of CeuB (data not shown).

\section{Ordering of the BssHIl fragments on the physical map}

The construction of the I-CeuI backbone of the NCP 262 genome resulted in the positioning of five BssHII fragments which were cleaved by I-CeuI, namely BssC, BssJ, BssB, BssF and BssH, with the latter three being linked (see Fig. 5). Another strategy was employed to determine the order and position of the remaining $B s s \mathrm{HII}$ fragments. This involved the preparation of a library of BssHII linking clones. To construct linking clones, pooled recombinant NCP 262 random pUC8 clones were digested with BssHII and ligated to a kanamycin cassette which had BssHII-compatible ends as described in Methods. These BssHII linking clones were used as probes to determine which BssHII fragments they hybridized with. Sequence was obtained from NCP 262 DNA flanking the kanamycin cassette in linking clones, and was used to carry out BLASTX and BLASTN searches. Linkages were confirmed when sequences flanking a BssHII site showed similarity to the same gene or protein, indicating that it spanned the site. Five linkages were established using this strategy (Table 5), with linking clone A10 reconfirming the linkage of $\mathrm{BssF}$ to $\mathrm{BssH}$ as already determined during the construction of the I-CeuI backbone. Sequences obtained from linking clones 26, 27, B10, B12, C4 and D4 (Table $5)$ showed no significant similarity to genes or proteins in the genebank databases. Therefore, linkages obtained using each of these clones were confirmed by PCR and Southern hybridization. Primers were designed from sequences obtained from each linking clone to amplify approximately $400 \mathrm{bp}$ regions spanning Bss HII sites from genomic DNA. The resulting PCR products were then used as probes to confirm linkages of the BssHII fragments.

Linking clones 26 and 27 (Table 5) were unexpectedly found to hybridize to single fragments (BssI and BssE, respectively), and PCR products were obtained from genomic DNA using primers designed from sequence flanking the Bss HII sites contained in these clones. This suggested that a small Bss HII fragment could be located between BssI and BssE, which was not resolved by PFGE. Consequently, these PCR products were labelled and used to probe Southern blots of BssHII-digested NCP 262 DNA separated by conventional agarose gel electrophoresis. Both were found to hybridize to a previously undetected $5 \mathrm{~kb}$ fragment which was designated $\mathrm{BssO}$ (Fig. 3).

In a number of cases, linking clones hybridized to more than two BssHII fragments due to the presence of repetitive DNA in the genome. Probes derived from short PCR products which spanned BssHII sites were therefore used to determine actual linkages. For example, linking clone $\mathrm{B} 10$ hybridized with $\mathrm{BssD}$, BssH and BssM, whereas a PCR product obtained from genomic template DNA using primers designed from the sequence flanking the Bss HII site of B10 hybridized only with BssD and BssM. However, linking clone B7 hybridized with fragments BssB, BssF, BssG, BssJ and BssN, and a $378 \mathrm{bp}$ PCR product spanning the BssHII site in linking clone B7 hybridized with BssB, BssG and $\mathrm{BssN}$, with the latter fragment appearing at higher intensity (Fig. 4a). A BLAST search of the sequences flanking the BssHII site from linking clone B7 revealed strong similarity to the IS element ISCb1 from $C$. beijerinckii (Table 5). Analysis of the ISCb1 sequence showed that it contained a BssHII site (Liyanage et al., 2000). We found that clone pEK30, containing a region of ISCb1 spanning the BssHII site, hybridized with BssB, BssG and BssN, with BssN again hybridizing at higher intensity (data not shown). To determine the copy number of the ISCb1-like IS element found on NCP 262, the PCR product (378 bp) obtained from B7 was used to 


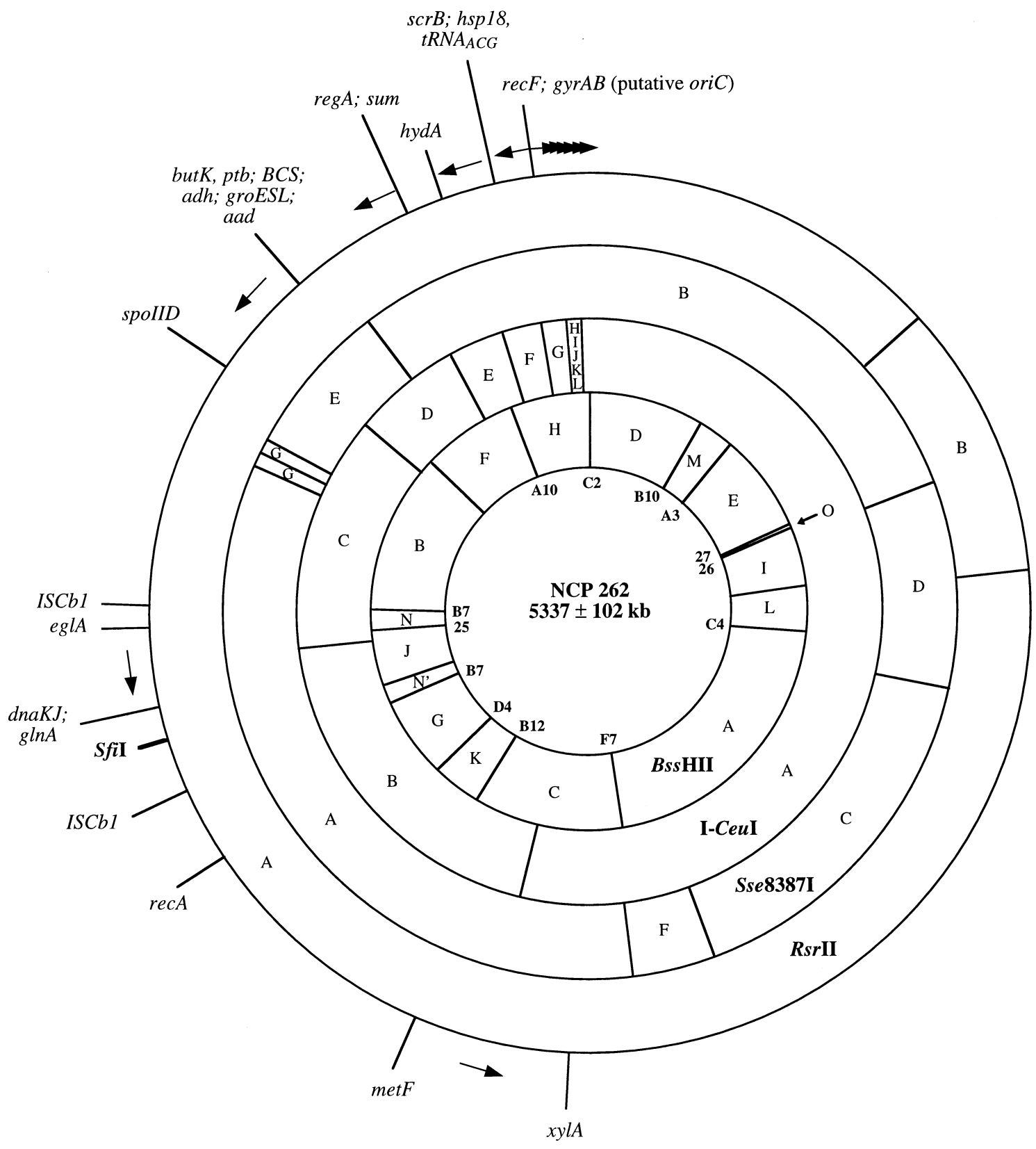

Fig. 5. Physical and genetic map of the C. saccharobutylicum NCP 262 genome. The arrows indicate the orientation of the ribosomal operons. The orientation of the $r r n$ operons lying within the Bss H fragment were determined; however, the order of the I-Ceul fragments bearing these operons has not been resolved. The genes are positioned on the map to the minimum region located by hybridization. The order of genes and/or operons given in a particular region is arbitrary. The BssHIl linking clones are given on the inside of the innermost circle. The positions of the following genes are indicated: adh1, alcohol dehydrogenase; aad, alcohol/aldehyde dehydrogenase; BCS, crt, bcd, etfAB, hbd genes in the BCS operon; butK, ptb, butyrate operon; dnaKJ, HSP70 coding gene cluster; eglA, endoglucanase; glnA, glutamine synthetase; hydA, hydrogenase; $h s p 18, t^{\prime n} a_{A C G}$, small heat-shock gene cluster; metF, methionine synthase; regA, $c c p A$ homologue; $\operatorname{rec} A$, multifunctional protein in homologous recombination; $\operatorname{rec} F$, gyrAB, homologous recombination protein, DNA gyrase subunits and putative origin of replication; scrB, sucrase operon; spollD, sporulation; sum, metronidazole susceptibility; $x y l A$, xylanase.

probe genomic digestion products obtained using the frequent-cutting enzymes EcoRV, HindIII and XbaI. The recognition sites for these enzymes were not present in the PCR product. Two fragments from each digest hybridized to the probe, indicating that two copies of the IS element are present on the NCP 262 genome (Fig. $4 \mathrm{~b})$. Hence, it was concluded that one copy of the IS element linked BssN to BssB and a second copy linked BssG to a second fragment, the same size as BssN, designated $\mathrm{BssN}^{\prime}$ (Fig. 5). 
Only two linkages remained to be resolved, namely the linkage of BssI to BssL and of BssJ to BssN' (Fig. 5). No linking clones were isolated which confirmed these links. To rule out the possibility of the presence of additional small BssHII fragments $(<5 \mathrm{~kb})$ lying between these BssHII fragments, BssHII-digested genomic NCP 262 DNA was ligated into the cloning vector pNEB193. Only clones containing the $5 \mathrm{~kb}$ BssO fragment were obtained and no other small BssHII fragments were cloned (data not shown). This indicated that the presence of further small BssHII fragments was unlikely, and analysis of both double digestions and Southern hybridizations linked BssJ to BssN' , and BssI to BssL (Fig. 5).

Wilkinson \& Young (1995) reported that some macrorestriction fragments in electrophoretograms from $C$. beijerinckii were overrepresented when compared with fragments of similar size. They suggested that fragments flanking the origin of replication are overrepresented due to the presence of multiple replication forks in genomic DNA extracted from cells during the exponential growth phase. The genomic DNA from NCP 262 was also isolated from cells in the exponential growth phase and the fragments $\mathrm{BssB}, \mathrm{BssD}, \mathrm{BssF}$ and $\mathrm{BssH}$, along with SseE, were found to be overrepresented in electrophoretograms, whereas the fragments BssC and SseF were underrepresented (Fig. 1). This suggested that the former fragments were near the origin of replication, whereas the latter two fragments were close to the replication terminus, and this was confirmed by the mapping data presented here.

\section{Location of genetic markers on the chromosome}

Cloned genes of homologous and heterologous origin (Table 1) were used to probe Southern blots of single and double digestions to determine gene positions on the physical map of the C. saccharobutylicum NCP 262 genome, and further confirmed the order, position and relatedness of macrorestriction fragments (Fig. 5). Genes identified from the linking clones (Table 5) do not appear on the map. Their positions are precisely known, in contrast to those shown, whose approximate positions have been determined by hybridization. The order of genes and/or operons assigned to the same fragment are arbitrary.

The positions of house-keeping genes, and genes involved in the heat-shock response and sporulation were determined, as was the location of some of the genes involved in electron transport and solvent production (Fig. 5). The C. acetobutylicum butanol dehydrogenase isozyme genes $(b d h A B)$ and coenzyme $\mathrm{A}(\mathrm{CoA})$-transferase genes $(c t f A B)$ did not hybridize to the genome of NCP 262.

\section{DISCUSSION}

A physical map of C. saccharobutylicum NCP 262 was constructed using PFGE and hybridization techniques. The size of the circular genome was estimated to be
$5.3 \mathrm{Mb}$, and a total of 39 restriction sites were positioned on the map using five restriction enzymes resulting in a mean resolution of approximately $140 \mathrm{~kb}$. The positions of 28 genes were determined, which represents a first step towards the construction of a genetic map of this bacterium.

The map was assembled using a number of complementary methods including PFGE, analysis of single and double digestion products, along with Southern hybridization, PCR and DNA sequence analysis of linking clones. The I-CeuI backbone was assembled using $r r s$ - and $3^{\prime} r r l$-specific probes located on either side of the I-CeuI site and reciprocal separation of Bss HII and I-CeuI digests by 2D-PFGE. C. saccharobutylicum NCP 262 has $12 \mathrm{rrn}$ operons located on $46 \%$ of the chromosome transcribed divergently from CeuG. At present, this is the second-highest number of $r r m$ operons reported, with C. beijerinckii NCIMB 8052 containing 14 , the most reported to date for a eubacterium (Wilkinson \& Young, 1998). Multiple copies of rrn operons are often found in bacterial species capable of rapid growth (Krawiec \& Riley, 1990). C. saccharobutylicum has a mean generation time of about $30 \mathrm{~min}$ under optimal conditions, a characteristic which favoured its use in industrial solvent production (McCutchan \& Hickey, 1954).

The B subunit of DNA gyrase $(g y r B)$ is located near the origin of replication in bacterial chromosomes (Salazar et al., 1996), and the C. acetobutylicum gyrB probe (Table 1) hybridized to CeuG, which also hybridized only with the $r r s$-specific probe and not the $3^{\prime} \mathrm{rrl}$-specific probe. Hence, the $12 \mathrm{rrn}$ operons of C. saccharobutylicum are transcribed confluently with the direction of chromosomal replication, which proceeds bidirectionally from an origin of replication located within CeuG to a terminus located within CeuA, and multiple copies of $r r n$ operons are clustered close to the replication origin.

The juxtaposition of the majority of the BssHII fragments was determined using a library of BssHII linking clones and Southern hybridization. Linkages were also confirmed by analysis of sequence obtained from regions flanking the BssHII sites present in linking clones. This analysis also allowed the mapping of a number of genes not previously reported for NCP 262 as listed in Table 5 . Many of the linking clones detected more than two $B s s \mathrm{HII}$ fragments when used as probes, indicating the presence of repetitive DNA on the NCP 262 chromosome. Analysis of one such linking clone led to the discovery of two copies of an insertion sequence very similar to ISCb1, an insertion sequence of the IS4 family isolated from C. beijerinckii NCIMB 8052 which contains a BssHII site (Liyanage et al., 2000).

The genes involved in controlling electron flow play an important role during the complex biphasic fermentation of carbohydrates to solvents in solvent-producing clostridia. Two of these genes, the iron-only hydrogenase (bydA) and the metronidazole susceptibility (sum) gene, were found to be near the replication origin 


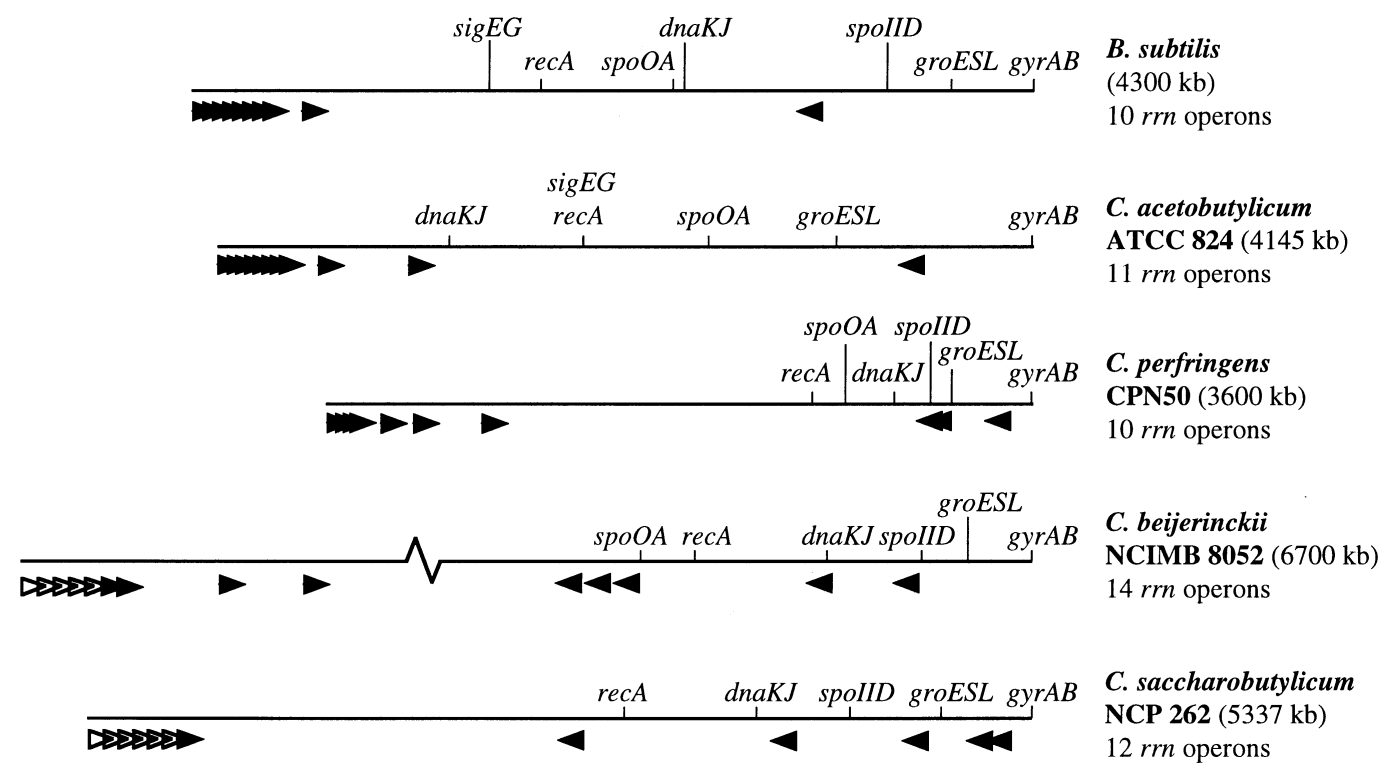

Fig. 6. Genome comparisons, as adapted from Cornillot et al. (1997), of the spore-forming bacteria $B$. subtilis (Anagnostopoulos et al., 1993), C. acetobutylicum (Cornillot et al., 1997), C. perfringens (Cole et al., 1998), C. beijerinckii (Wilkinson \& Young, 1998) and C. saccharobutylicum. To facilitate comparisons, the circular chromosomes were opened and aligned at the putative origin of replication, corresponding to the gyrAB genes. The arrows indicate $r r n$ operons. Open arrows correspond to $r$ rn operons whose orientations have not been confirmed.

in C. saccharobutylicum, with the former gene also reported to be close to the origin of replication in $C$. acetobutylicum (Cornillot et al., 1997).

Some of the genes involved in the acid- and solventforming pathway were found to be clustered in a small region, representing only $2.5 \%$ of the NCP 262 genome. This included the butyryl-CoA synthesis (BCS) operon genes, $c r t, b c d$, etf $A B$ and $h b d$, which reduce acetoacetylCoA to butyryl-CoA in three consecutive reactions, and the butyrate operon genes, $p t b$ and $b u t K$, involved in the conversion of butyryl-CoA to butyrate. The BCS operon was found to be in close proximity to the groESL heatshock operon, as is the case for both C. acetobutylicum (Cornillot et al., 1997) and C. beijerinckii (Wilkinson \& Young, 1995). The adh1 gene isolated from C. saccharobutylicum NCP 262 was reported to be downstream from the hbd gene (Youngleson et al., 1989); hence it was located on the same region as the BCS operon. This NADPH-dependent alcohol dehydrogenase was shown to have activity using butanol and ethanol as substrates (Youngleson et al., 1989). The genes involved in the final steps of solvent production are the aldehyde/alcohol dehydrogenase (aad) and CoA-transferase (ctfAB) genes, which form the sol operon (Dürre et al., 1995), along with the acetoacetate decarboxylase $(a d c)$ and butanol dehydrogenase $(b d h A B)$ genes. Toth et al. (1999) reported that a probe derived from the C. acetobutylicum aad gene did not hybridize to three species of solvent-producing clostridia, including C. saccharobutylicum NCP 262. However, we have recently isolated a gene from C. saccharobutylicum NCP 262 with significant similarity to the C. acetobutylicum aad gene (unpublished results). It is located on the genome together with the other genes concerned with solvent and acid production (Fig. 5). The $b d h A B$ genes and the bifunctional aad gene are involved in butanol formation, and the $c t f A B$ and $a d c$ genes convert acetoacetyl-CoA to acetone, and are therefore very likely to be found on the NCP 262 genome. However, the C. acetobutylicum probes for the genes $c t f A B$ and $b d h A B$ did not hybridize with the NCP 262 genome under the conditions we used. Taken together, these results suggest that there is considerable sequence divergence between certain solvent-producing genes found in the solvent-producing clostridia. Further studies are under way to identify and sequence the remaining sol cluster genes of NCP 262.

The genome size and organization of C. saccharobutylicum were compared with those of the sporeforming bacteria B. subtilis, C. acetobutylicum, C. perfringens and C. beijerinckii (Fig. 6). The genome of C. saccharobutylicum was smaller than that of $C$. beijerinckii but larger than the genomes of the other three spore-forming bacteria. On the basis of genome organization, C. saccharobutylicum is most similar to C. beijerinckii and C. perfringens, with the order of the genes gyrAB, groESL, spoIID, dnaKJ and recA being conserved. In addition, several $r r n$ operons in $C$. beijerinckii, C. perfringens and C. saccharobutylicum are transcribed divergently from the origin of replication, as opposed to only one $r r n$ operon being transcribed divergently to the remaining $r r n$ operons in C. acetobutylicum and B. subtilis.

The construction of a physical map and the initiation of a genetic map of NCP 262 has provided preliminary insight into the genome structure of this industrially 
important bacterium. Only one other industrial solventproducing Clostridium species, 'C. saccharoperbutylacetonicum', remains to be mapped. It would be of interest to compare its genome organization to those of the other three solvent-producing Clostridium species, to gain further insight into the relationships that exist between their genome size and structure, and the location of the sporulation and solventogenesis genes.

\section{ACKNOWLEDGEMENTS}

We would like to thank Shez Reid for providing cloned NCP 262 and C. beijerinckii NCIMB 8052 genes, Phillippe Soucaille for cloned C. acetobutylicum ATCC 824 genes and rRNA probes, and Mike Young for the pEK30 plasmid containing part of the insertion sequence, ISCb1. We would also like to thank Paul Rainey at Oxford University for allowing S. K. to visit his laboratory and showing her the procedure of $2 \mathrm{D}$ PFGE. S.K. was in receipt of a Commonwealth Science Council Fellowship to fund this visit. This work was funded by a grant from the Lotteries Board and an Otago Research Grant.

\section{REFERENCES}

Altschul, S. F., Madden, T. L., Schäffer, A. A., Zhang, J., Zhang, Z., Miller, W. \& Lipman, D. J. (1997). Gapped BLAST and PSI-BLAST : a new generation of protein database search programs. Nucleic Acids Res 25, 3389-3402.

Anagnostopoulos, C., Piggot, P. J. \& Hoch, J. A. (1993). The genetic map of Bacillus subtilis. In Bacillus subtilis and Other Gram-positive Bacteria: Biochemistry, Physiology, and Molecular Genetics, pp. 425-461. Edited by A. L. Sonenshein, J. A. Hoch \& R. Losick. Washington, DC: American Society for Microbiology.

Andersson, B., Wentland, M. A., Ricafrente, J. Y., Liu, W. \& Gibbs, R. A. (1996). A "double adaptor" method for improved shotgun library construction. Anal Biochem 236, 107-113.

Boynton, Z. L., Bennett, G. N. \& Rudolf, F. B. (1996). Cloning, sequencing, and expression of clustered genes encoding $\beta$ hydroxybutyryl-coenzyme A (CoA) dehydrogenase, crotonase, and butyryl-CoA dehydrogenase from Clostridium acetobutylicum ATCC 824. J Bacteriol 178, 3015-3024.

Cary, J. W., Petersen, D. J., Papoutsakis, E. T. \& Bennett, G. N. (1990). Cloning and expression of Clostridium acetobutylicum ATCC 824 acetoacetyl-coenzyme A: acetate/butyrate:coenzyme A-transferase in Escherichia coli. Appl Environ Microbiol 56, 1576-1583.

Church, G. M. \& Gilbert, W. (1984). Genomic sequencing. Proc Natl Acad Sci US A 81, 1991-1995.

Cole, S. T., Katayama, S.-I., Dupuy, B., Garnier, T., Saint-Joanis, B. \& Canard, B. (1998). Clostridium perfringens CPN50. In Bacterial Genomes. Physical Structure and Analysis, pp. 645-647. Edited by F. J. de Bruijn, J. R. Lupski \& G. M. Weinstock. New York: Chapman \& Hall.

Collett, H. J., Woods, D. R. \& Reid, S. J. (1997). Characterisation of a transposon-induced pleiotropic mutant of Clostridium acetobutylicum P262. Anaerobe 3, 411-421.

Cornillot, E., Croux, C. \& Soucaille, P. (1997). Physical and genetic map of the Clostridium acetobutylicum ATCC 824 chromosome. J Bacteriol 179, 7426-7434.

Davison, S. P., Santangelo, J. D., Reid, S. J. \& Woods, D. R. (1995). A Clostridium acetobutylicum regulator gene (regA) affecting amylase production in Bacillus subtilis. Microbiology 141, 989-996.

Dürre, P., Fischer, R.-J., Kuhn, A., Lorenz, K., Schreiber, W., Stürzenhofecker, B., Ullmann, S., Winzer, K. \& Sauer, U. (1995). Solventogenic enzymes of Clostridium acetobutylicum: catalytic properties, genetic organization, and transcriptional regulation. FEMS Microbiol Rev 17, 251-262.

Gorwa, M.-F., Croux, C. \& Soucaille, P. (1996). Molecular characterization and transcriptional analysis of the putative hydrogenase gene of Clostridium acetobutylicum ATCC 824. J Bacteriol 178, 2668-2675.

Hanahan, D., Jessee, J. \& Bloom, F. R. (1991). Plasmid transformation of Escherichia coli and other bacteria. Methods Enzymol 204, 63-113.

Janssen, P., Jones, W. A., Jones, D. T. \& Woods, D. R. (1988). Molecular analysis and regulation of the $g \ln A$ gene of the grampositive anaerobe Clostridium acetobutylicum. J Bacteriol 170, 400-408.

Johnson, J. L., Toth, J., Santiwatanakul, S. \& Chen, J. S. (1997). Cultures of "Clostridium acetobutylicum" from various collections comprise Clostridium acetobutylicum, Clostridium beijerinckii, and two other distinct types based on DNA-DNA reassociation. Int J Syst Bacteriol 47, 420-424.

Jones, D. T. \& Keis, S. (1995). Origins and relationships of industrial solvent-producing clostridial strains. FEMS Microbiol Rev 17, 223-232.

Jones, D. T. \& Woods, D. R. (1986). Acetone-butanol fermentation revisited. Microbiol Rev 50, 484-524.

Keis, S., Bennett, C. F., Ward, V. K. \& Jones, D. T. (1995). Taxonomy and phylogeny of industrial solvent-producing clostridia. Int J Syst Bacteriol 45, 693-705.

Krawiec, S. \& Riley, M. (1990). Organization of the bacterial chromosome. Microbiol Rev 54, 502-539.

Liyanage, H., Holcroft, P., Evans, V. J., Keis, S., Wilkinson, S. R., Kashket, E. R. \& Young, M. (2000). A new insertion sequence, ISCb1, from Clostridium beijerinckii NCIMB 8052. J Mol Microbiol Biotechnol 2, 107-113.

McClelland, M., Hanish, J., Nelson, M. \& Patel, Y. (1988). KGB: a single buffer for all restriction endonucleases. Nucleic Acids Res 16, 364.

McCutchan, W. N. \& Hickey, R. J. (1954). The butanol-acetone fermentations. In Industrial Fermentations, vol. 1, pp. 347-388. Edited by L. A. Underkofler \& R. J. Hickey. New York: Chemical Publishing.

Narberhaus, F. \& Bahl, H. (1992). Cloning, sequencing, and molecular analysis of the groESL operon of Clostridium acetobutylicum. J Bacteriol 174, 3282-3289.

Narberhaus, F., Giebeler, K. \& Bahl, H. (1992). Molecular characterization of the $d n a K$ gene region of Clostridium acetobutylicum, including grpE, dnaJ, and a new heat shock gene. J Bacteriol 174, 3290-3299.

O'Brien, R. W. \& Morris, J. G. (1971). Oxygen and the growth and metabolism of Clostridium acetobutylicum. J Gen Microbiol 68, 307-318.

Reid, S. J., Rafudeen, M. S. \& Leat, N. G. (1999). The genes controlling sucrose utilization in Clostridium beijerinckii NCIMB 8052 constitute an operon. Microbiology 145, 1461-1472.

Salazar, L., Fshihi, H., de Rossi, E., Riccardi, G., Rios, C., Cole, S. T. \& Takiff, H. E. (1996). Organization of the origins of replication of the chromosomes of Mycobacterium smegmatis, Mycobacterium leprae, and Mycobacterium tuberculosis and isolation of a functional origin from M. smegmatis. Mol Microbiol 20, 283-293. 
Sambrook, J., Fritsch, E. F. \& Maniatis, T. (1989). Molecular Cloning: a Laboratory Manual, 2nd edn. Cold Spring Harbor, NY : Cold Spring Harbor Laboratory.

Sauer, U. \& Dürre, P. (1993). Sequence and molecular characterization of a DNA region encoding a small heat shock protein of Clostridium acetobutylicum. J Bacteriol 175, 3394-3400.

Shaheen, R., Shirley, M. \& Jones, D. T. (2000). Comparative fermentation studies of industrial strains belonging to four species of solvent-producing clostridia. J Mol Microbiol Biotechnol 2, 115-124.

Stutz, H. (2000). Regulation and characterization of the nitrogen assimilatory gene cluster in Clostridium acetobutylicum P262. $\mathrm{PhD}$ thesis, University of Cape Town.

Toth, J., Ismaiel, A. A. \& Chen, J.-S. (1999). The ald gene, encoding a coenzyme A-acylating aldehyde dehydrogenase, distinguishes Clostridium beijerinckii and two other solvent-producing clostridia from Clostridium acetobutylicum. Appl Environ Microbiol 65, 4973-4980.

Ullmann, S. \& Dürre, P. (1996). Nucleotide sequence and molecular characterization of the DNA gyrase genes from Clostridium acetobutylicum. Anaerobe 2, 239-248.

Vieira, J. \& Messing, J. (1982). The pUC plasmids, an M13mp7derived system for insertion mutagenesis and sequencing with synthetic universal primers. Gene 19, 259-268.

Walter, K. A., Bennett, G. N. \& Papoutsakis, E. T. (1992). Molecular characterization of Clostridium acetobutylicum ATCC 824 butanol dehydrogenase isozyme genes. J Bacteriol 174, 7149-7158.

Walter, K. A., Nair, R. V., Cary, J. W., Bennett, G. N. \&
Papoutsakis, E. T. (1993). Sequence and arrangement of two genes of the butyrate-synthesis pathway of Clostridium acetobutylicum ATCC 824. Gene 134, 107-111.

Wilkinson, S. R. \& Young, M. (1995). Physical map of the Clostridium beijerinckii (formerly Clostridium acetobutylicum) NCIMB 8052 chromosome. J Bacteriol 177, 439-448.

Wilkinson, S. R. \& Young, M. (1998). Clostridium beijerinckii NCIMB 8052 chromosome. In Bacterial Genomes. Physical Structure and Analysis, pp. 641-644. Edited by F. J. de Bruijn, J. R. Lupski \& G. M. Weinstock. New York: Chapman \& Hall.

Yanisch-Perron, C., Vieira, J. \& Messing, J. (1985). Improved M13 phage cloning vectors and host strains: nucleotide sequences of the M13mp18 and pUC19 vectors. Gene 33, 103-119.

Youngleson, J. S., Jones, D. T. \& Woods, D. R. (1989). Homology between hydroxybutyryl and hydroxyacyl coenzyme A dehydrogenase enzymes from Clostridium acetobutylicum fermentation and vertebrate fatty acid $\beta$-oxidation pathways. J Bacteriol 171, 6800-6807.

Zappe, H., Jones, D. T. \& Woods, D. R. (1986). Cloning and expression of Clostridium acetobutylicum endoglucanase, cellobiase and amino acid biosynthesis genes in Escherichia coli. J Gen Microbiol 132, 1367-1372.

Zappe, H., Jones, D. T. \& Woods, D. R. (1987). Cloning and expression of a xylanase gene from Clostridium acetobutylicum P262 in Escherichia coli. Appl Microbiol Biotechnol 27, 57-63.

Received 24 November 2000; revised 10 March 2001; accepted 23 March 2001. 